\title{
Mathematics Metacognitive Skills of Papua's Students in Solving Mathematics Problems
}

\author{
Awaluddin Tjalla ${ }^{1} \&$ Maria Fransiska Putriyani ${ }^{2}$ \\ ${ }^{1}$ Department of Guidance and Counseling Faculty of Education, State University of Jakarta, Jakarta, Indonesia \\ ${ }^{2}$ Department of Research and Education Evaluation, Postgraduate School State University of Jakarta, Jakarta, \\ Indonesia \\ Correspondence: Awaluddin Tjalla. E-mail: awaluddin.tjalla@gmail.com; anniefransis@gmail.com
}

\author{
Received: February 23, 2018 Accepted: March 13, $2018 \quad$ Online Published: June 22, 2018 \\ doi:10.5539/ass.v14n7p14 URL: https://doi.org/10.5539/ass.v14n7p14
}

\begin{abstract}
This research focuses on the analysis of mathematics metacognitive skills of Papua's students in School of Indonesian Children in solving mathematics learning problems. The research was conducted to provide a good quality education for Papuan students, so the research start the research from the metacognitive skills especially in mathematics. The respondents of the research are 6 students from grade VII in School of Indonesian Children. Those respondents are represent of higher mathematical ability, medium mathematical ability, and lower mathematical ability. The research used descriptive qualitative research method. Data collection procedures used in this research was in-depth interview and participant observation as well as documents related to metacognitive process in solving the problems in learning mathematics. The in-depth interview was with the respondents, the Principal, the mathematical teacher and the Character Building teacher. For documents related to metacognitive process in solving the problems in learning mathematics such as the result national exam in elementary, the result daily test of math, the result of quiz or homework. In general, the students in Papua were lack of mathematics metacognitive ability such as, lack of cognitive knowledge and cognitive regulation, sometimes they cannot perform the activities that reflects conscious metacognitive such as mathematics problem solving. The research result indicates that the structure metacognitive ability of students in Papua influences their problem solving ability in learning mathematics. This metacognitive ability is also influenced by the fact that it becomes their characteristics background as respondents from Papua.
\end{abstract}

Keywords: metacognitive skills, cognitive knowledge, learning, Papua's students, solving mathematics problems

\section{Introduction}

Indonesia is a country in Southeast Asia. The world map shows that Indonesia has many islands, so Indonesia is called as an archipelagic country. One of the Indonesian islands that located in the east and the most wide island with the smallest population is Irian Jaya or referred to as Papua since 2001. Papua is very different than Special Capital Region of Jakarta, which is the most narrow province with the largest population. With the smallest population, then Papua became the one of the destination for transmigrans.

Papua is a province with a rich natural resources but this does not in line with the human resources. Most native Papua recently still have under-developed way of thinking. In international world, Papua has been well known as the most left behind area in terms of transportation, public facilities, government, and most importantly, education. Papua people, who are living in the city, have so much money, lands, and they can go to Java islands and other islands to have fun without thinking about their future. One of the main reasons of chaos that trigger conflicts among the people of Papua is alcohol. This alcoholic drink is also the cause of 'the genocide' of the young generation in Papua.

Indonesia has not been able to provide good quality education equally to all parts of Indonesia. There are many things become the obstacles, particularly in developing a good quality education in remote areas such as in Papua. In 2010, there were in total 553.290 out of 1.270 .150 school age children (aged 0-19 years old) all over Papua did not have opportunity to have education (Wetipo \& Medlama, 2015). The reasons of this situation in Papua were because those children came from low income family, their neighborhood and society were not 
supportive and not conducive, their houses were located in a difficult geographical area, and there were not enough teachers available to teach in schools in those areas.

All things mentioned above have created a negative stigma in our society towards the local Papua people, in general, that the native young generation from Papua "lack of" thinking ability. Many colleagues at the works also find it difficult to work with the native Papua people.

As one of the richest province in Indonesia, Province of Papua has sent many native Papua youth to study outside Papua area. The purpose is to enable the native youth of Papua to get a proper and better education compared to those who study in Papua. In addition, it also aims to allow the native youth of Papua to understand the outside world related to their own tradition and customs, so they will be able to select between good and bad tradition, without losing their cultural root. It is expected that after accomplishing their study outside of Papua, they will bring better change to Papua.

The native youth of Papua who were sent to study in other places in Indonesia experienced a little complicated adaptation process, moreover if they came from the remote area of Papua. The adaptation process they were facing included adaptation in daily life habit and learning process at schools. In their daily life, they must adapt to live in dormitory that demand high discipline and responsibility with all regulation applied. Besides, they also experienced adaptation process to receive learning materials that they had never received as long as they lived in Papua. They must work hard in those two adaptation processes.

One of schools that become the target place to study is School of Indonesian Children. School of Indonesian Children is a boarding school that located in Bogor, West Java. The students who are studying in School of Indonesian Children are all from Papua. They live in a dormitory located next to the school building. The research respondents came from two regencies in Papua: Tambrauw and Membramo Raya. They have different family background, such as farmer, Civil Servant, and fisherman.

The VII grade students of Junior High School in School of Indonesian Children were those who graduated from Elementary School of Indonesian Children Batch 2015. They came to Jakarta for the first time without well preparation. Some of them did not even know that they would be brought to Jakarta to study. They were accepted in School of Indonesian Children at the Fourth grade of Elementary School. However, they must work hard because the learning was started from the First grade of elementary school materials. This was because most of them could not read and write, their knowledge only limited to knowing alphabet and numbers 1-100. These shortages had made them experiencing difficulties in mathematics lesson. Based on the pre-observation conducted by the researcher in Grade VII Junior High School of School of Indonesian Children, it was found that the students at Grade VII had difficulties in solving the problems in narrative questions in studying mathematics at school, for example: they could not understand the problem, needed many key words to help them, could not think forward and backward, and needed more time to solve a problem. Some of the students explained that this could happen because they must adapt themselves to several changes, such as mathematics materials were more complex and abstract, different teachers, different ways of teaching, etc. Briefly, the students experienced a problem on thinking ability.

In Indonesia, mathematics is taught on every stage of education. The general purpose of teaching mathematics are: (1) to prepare the students to face the changing situation in life and in the changing world, through action training based on logic, rational, critical, meticulous, honest, effective and efficient thinking, and (2) to prepare students to use mathematics and mathematics thinking pattern in daily life and in learning various sciences.

Mathematics materials chosen to be taught at school are designed to make it easily applied in the students' life. Counting is a branch of mathematics that discusses about numbers and its operational counting that covers (addition, reduction, multiplication, division, power, square root, and logarithm deduction).

One of mathematics materials at Grade VII Junior High School applied in daily life is social arithmetic. Social arithmetic is actually material about the use of algebra concept in solving social problem or problems that are faced in daily life. Social arithmetic materials are included in an advanced algebra materials with competence standard (CS) in which it uses algebra form, equality and inequality, and comparison in problem solving. One of the basic competences (BC) is the use of algebra concept in solving a simple social arithmetic problem. In studying social arithmetic, students will learn about buying price, selling price, benefit, loss, discount, gross, calibration, net, saving interest, and tax. All of the lesson materials consist of problem case that often faced in daily life.

The students in Papua are facing difficulty on social arithmetic material, particularly when they have narrative question. Some of the students explained that they have difficulty because they must adapt themselves to several 
changes from Elementary School to Junior High School, for example more complex and abstract mathematics materials, different teachers, different teaching method, etc. Therefore, this research was conducted to analyze the metacognitive ability of native Papua students. It is expected to find out the thinking process of the native Papua students in solving the problem on mathematics learning, particularly the social arithmetic materials.

\section{Literature Review}

Success factor of children in the future depends on how optimal the development of all aspects in themselves including physical, cognitive, emotional, and spiritual development. One of development aspects that always become the main focus is the cognitive development. A child who has an optimal cognitive development will definitely have cognitive ability. This cognitive ability will determine the child intellectual intelligence (Santrock, 2001). This cognitive ability will keep growing along with the educational process as well as the child care pattern and surrounding environment. The cognitive ability development is continuing in line with the child growth, one of it is how to manage and arrange that ability in coping with problems. The cognitive aspects cannot grow by themselves separately, it has to be controlled or arranged in some ways. Hence, someone must have awareness about his/her thinking ability and can arrange it, this is what is called metacognitive.

Metacognitive ability is knowledge about cognitive that control, monitor, and arrange the cognitive (Schraw \& Dennison, 1994). Metacognitive ability appears to be someone's ability to explain their knowledge and implement it to learn new knowledge that has not been learned. Metacognitive ability helps the students in choosing the appropriate cognitive tool to study.

Metacognitive can be simply defined as the thinking about thinking. According to Krathwohl (2002), metacognitive is "knowledge about cognition in general as well as awareness of and knowledge about one's own cognition." Metacognitive ability is a part of what is called as metacognitive strategic process. Metacognitive ability is also a part of self-arrangement process, the ability to control the self-thinking process in every stage of problem solving. At each stage (orientation, organization, execution, and verification), each student must monitor his/her thinking and at the same time he/she also must make various decisions in conducting the stage he/she has chosen. To finish the problem well, the student must re-question the answer he/she has made to see if the answer is correct and whether there is another more effective way in solving the problem given to him/her.

A simple metacognitive process in completing the assignments given covers: understanding and controlling the student's learning processes. Furthermore, based on Brown (1987), Flavell (1987), and Jacobs \& Paris (1987) as it is quoted by Schraw \& Dennison (1994), metacognitive is divided into two big components, i.e. cognitive knowledge and cognitive regulation. Cognitive knowledge is further divided into three sub-processes that indicates the metacognitive dimension, they are: Declarative knowledge (It is knowledge about ourselves and strategy), Procedural knowledge (it is the knowledge about how to use the strategy), Conditional knowledge (It is the knowledge about why and when a strategy is used).

Cognitive regulation consists of several sub-parts that indicate controlling aspect from studying. Based on Artzt \& Armour-Thomas (1992) and Baker (1992) as quoted by Schraw and Dennison (1994), there are five dimensional components of cognitive regulation, that is; planning, information management strategy, understanding monitoring, debugging strategy, and evaluation. Those five sub-processes are used or applied in the process of problem solving in mathematics lesson. When a student wants to finish a mathematics problem, then the first step to do is to understand that problem, then plan the completion process, arrange the information of the problem that will be used, stop and re-read the problem if there is difficulty found (debugging strategy), and evaluate it when the problem solved. The problems in social arithmetic are problems that the students will face in their daily life. If the native Papua students at Grade VII succeed in understanding this mathematics material, then they will be more confident in facing the mathematics process in their real life. Most Papua people thought that the new comers from the Islands of Java, Sumatra, Sulawesi, and others are bad and deceitful people, particularly in the trading related to money. This is because Papua people do not understand the counting process in buying and selling.

Mathematics is also a tool to develop the students' way of thinking. The role of mathematics as a basic science has strategic values in developing the way to think logically, to act critically, and to behave rationally. The role of mathematics is very important in the keep moving and changing world. Mathematics is needed in every aspect of life, as stated by NCTM (2000): Mathematics for life, Mathematics as a part of cultural heritage, Mathematics for the workplace, Mathematics for the scientific and technical community. In mathematics, there is as problem solving process. Solving a problem is a basic activity for human being. Therefore, one of the things that need our attention in learning mathematics is the problem solving ability. According to Branca in Susiyati (2014) the ability includes: (1) ability to solve the problem is the general purpose of mathematics teaching, (2) problem 
solving that includes method, procedures, and strategy is the core and primary process in mathematics curriculum, and (3) problem solving is a basic ability in mathematics learning.

George Polya (in Anom, 2005) identified general steps that should be conducted by each individual in solving the problem:

a. Understanding the problem:

Students understanding the problems;

b. Developing a plan for problem solving;

Students choose the best appropriate strategy to solve the problem;

c. Operationalizing the plan;

All plans that have been made then conducted one by one.

d. Review the answer and its process:

Re-check the steps from the beginning to the end.

Problems in mathematics lesson are questions and tasks that must be finished by students. The problem solving is the order of processes taken in solving or answering the questions and tasks. The problem solving process will involve several information that cover concepts or mathematics principles. By using problem solving approach, mathematics aspects can be developed, that is the skills needed to solve the daily problems.

Mathematics problem solving is a process with several steps to be done by someone by using thinking patterns, organizing and using logical prove in solving the problems, or in other word, mathematics problem solving needs high level of intellectual skill. In the problem solving process during their study, the students are asked to remember all the previous rules. This is because this learning time is always connected with the previous learning experience. In remembering the previous rules, the students must acquire several concrete concepts, and in learning those concepts, students have to study several discrimination/differences between materials.

Papua people are divided into two big parts, that is, mountainous or high land of Papua or seaside or low land of Papua. Based on those two big parts, the people of Papua are further divided into several small ethnics with different languages for each ethnic. The origin of Papua people are still holding the traditional belief they are believe in. They combine between material and spiritual worlds that have similar functions. The inland of Papua are accustomed and form their knowledge that the shaman is the source of solution for all symptoms (Supriyono, 2010).

The Papuan people have many different languages depending on their respective ethnic. This language differences makes them difficult to communicate. In general, Papuans who speak Indonesian are people living in the city, close to migrants. Ethnics who live in the inland/forest sometimes can not speak Indonesian. Language has an important role in one's intellectual, social and emotional development (FIP UPI, 2007). In education, language is one of the key to success in learning something.

Children of Papua are very simple and frequently appear very naïve. Some of them are primitive in many ways. Moreover, a few of young people of Papua seem to be living in a different world. They are alienated and feel nervous (worried and confused) with the advanced development of their surrounding world. These Papua children feel so worried to enter a confusing daily world (Supriyono, 2010). Furthermore, the physical characteristics of Papua are very different from most of Indonesian people who are the descendants of Malay families. According to the definition of Special Autonomy Clause 1 Letter $(t)$ about the native Papua: Native Papua people are people from Melanesia race families consists of native ethnics in Papua Province and/or people who are accepted and admitted as the native Papua by the indigenous society of Papua (Widjojo, 2009). Melanesia families have characteristics such as dark skin and curly hair, parts of Indonesia that are categorized as Melanesia families are the eastern part of Indonesia: Papua, Maluku, and Nusa Tenggara Timur.

Generally, most people have negative image about Papua people. In fact, Papua people have unique characteristics. They are full of naivety, sincerity, and peacefulness. The violence occurs in Papua is triggered by their own naivety, they trust others too much easily, this trust relates to their own naivety.

For Papua people, the nature is a practical solution. Almost all solutions for every problem are looked for on the surface of the land, on the plants, animal hunting, etc. The nature is the answer for their needs. In short, the nature has provided everything for them and they only need to take from it. The experience over the nature has become a variable that cannot be interfered in every choice made by Papua people. Having longer time to think, or in other word, having a process, and postponing needs are not the habit of Papua people. Every time they need 
something, they will directly try to fulfill their needs at the same time. In their way of thinking, the nature has provided everything, so human beings do not have to do lots of efforts.

The awareness of life is a long process in a very limited time. The concept of time for Papua people is today. They do not even divide the concept of 'today' time into hour or minute. Therefore, imagining life as a planned process is only a figment. The advancement has not yet seen as a long process that need to be prepared from today. The paradigm "today only" has become their part of life. For example: the assignments from school are finished just before the due date of the submission. In Papua, many times the problems are not analyzed to get the source of the problem. It is easier to find the black goat or to blame others. For them, any problem can be finished immediately, and there is no need to recognize the root of the problem. This has become their daily habit.

Relation of the society in the remote area is indeed not in harmony. Prejudice to other groups is still strong and it leads to a conflict easily. The rivalry between families or ethnics is also very strong. They have to prevent others to succeed because others' success is a threat, particularly if they cannot do the same success. Before the threat comes to reality, the potential people who can become threat must be eliminated or conquered by using various ways, but the most frequently used method is by using witchcraft or voodoo.

The success of an individual or some people in a group of people is a source of happiness for that group. If someone succeed to have a high position in the governmental structure, then that person "responsible" for other people in the family. This kind of success is strong enough to cause a jealousy. This jealousy can indirectly explode hatred. However, if one day there is a problem with that successful group, even if only a small one, then other groups will use that problem as a tool to express their jealousy.

For Papua people, women are 'tools' to cook and men are their master. Women are also a symbol of social status and power. Rich people will empower their status by having several wives. In their daily life, women are not only symbol of power, but also free labor. The responsibilities for plantation or pig farm are given to women. The wider the plantation and the more cattle they have, the more women need to be taken. Socially, men with many wives are considered have strong charisma, so they become someone to whom the people can ask for advices. This way of thinking has resulted the women in Papua are very vulnerable to violence or unfair treatment and they cannot do anything about it. Papua women appear to be a powerful 'tools' but prone to violence and oppression.

The future of human resource in Papua must be prepared earlier by providing good quality of education. Education in Papua should be modern but allow them to keep their local values to preserve the local culture. Education is the answer and the gate to see a better change in Papua in the future.

\section{Method}

Research method used in this research was qualitative research method. The primary technique of data collection procedures conducted in this research was observation, in-depth interview, and documents related to the metacognitive ability in mathematics problem solving (Creswell, 2012). The researcher do some interviews to each respondent, headmaster of Junior High School, mathematic teacher of grade VII, character building teacher and homeroom teacher of grade VII.

In conducting the research, the researcher was directly involved and observed the learning process, because the researcher is a teacher in there. The researcher attended mathematics lesson in Grade VII and stayed in dormitory in the efforts of observing the daily life of the observed subject in relation to metacognitive process in mathematics problem solving. The respondent welcomed the researcher and did not know if they were being researched. The observed objects were the description of mathematics logical thinking process, teaching learning activities, and the children's daily activities in doing their tasks or studying or in doing their homework. The data sources collected in this research covered bio-data of students in Grade VII Junior High School in Indonesian Children with their scores of National Examination/School Examination from Elementary School, written documents such as annual working program, semester working program, schools rules, collection of school homework, formative test, the utterances and attitude of teachers, students, staff and supervisors of School of Indonesian Children dormitory that were collected in the form written notes, photos, and video recordings.

The total number of students of Grade VII Junior High School in the School of Indonesian Children are 17 consist of 7 male students and 10 female students. Those 17 students come from 3 (three) different regencies: 12 from Tambrauw regency, 4 (four) from Membramo regency, and 1 (one) from Tolikara regency. There are 16 out of 17 students graduated from Elementary School in the School of Indonesian Children of who took their Elementary School examination in Bogor. Those 16 students are native Papua children Batch 2012, means that 
they were accepted in School of Indonesian Children in 2012. Whereas, one (1) student is Batch 2015, this student was accepted in School of Indonesian Children in August 2015. When they were accepted in School of Indonesian Children, the students took Matriculation class for at least 3 months. If the result is "good" means the skills that they have are match with the grade/level, then they will directly join the normal class, Grade VII.

From those 17 students, the researcher took only 6 students as the representative respondent. The respondents of research were selected by the researchers based on the data obtained from the results of mathematics national exam in elementary, opinion of Character Building teacher in junior high school and opinion of mathematics teachers grade VII. The respondents are represent for 3 categories, as higher mathematical ability (DB and JG), middle mathematical ability (DY and LD), and lower mathematical ability (YR and CE).

\section{The Result of Research}

The researcher conducted observation when the students study social arithmetic, in which they studied about buying prices, selling prices, profit, loss, discount, gross, tare, net, saving interest, and tax. All those learning materials were problematic cases that are frequently found in daily life. These materials are very important for their daily life. Based on the story that the researcher got from some students, They said that many Papua people are so easily deceived in buying-selling processes, for the unclear reasons, either because of they are lazy or do not know how to count.

Language is perhaps the most frequently cited contributor to ethnic identity (Hurtado \& Gurin, 1995). Ingroup speech can serve as symbol of ethnic identity and cultural solidarity. It is used for reminding the group about its cultural heritage, for transmitting group feelings and for excluding members of outgroup from its internal transactions (Miller \& Hoogstra, 1992). Sometimes, the Papuan students in SAI speak Papuan when they were resting or gathering in dormitories, whereas no teacher is able to speak the Papuan language, the teacher only knows some vocabulary of Papuan language. The students of class VII when they come to SAI can speak Indonesia, but sometimes there are some vocabulary in Indonesian that they do not understand (the meaning). They have difficulty when they have to speak standard Indonesian. This affects their understanding of the subject matter.

In the learning process in School of Indonesian Children, Grade VII students were highly dependent on the teachers. They trust their teachers, so even if they were told a lie, they were not aware of it. Mathematics teachers at Grade VII in School of Indonesian Children taught social arithmetic concept by relating it to daily problem, especially economic field. During the learning process, the teacher sometimes asked easy question, for example "what does discount mean?" The students answered enthusiastically, all answered the question at the same time, so the class was so noisy. However, in that enthusiastic answer, some of them answered the question without thinking about anything.

In doing their tasks, Grade VII students were divided into several groups: some worked seriously, some were working and joking, and others did nothing and cheated from their friends. All of them are not aware of school culture, not to mention the metacognitive ability. They were flow with the situation in Papua even though they have lived in School of Indonesian Children since 2012. In this materials, the difficulties faced by the respondents with high mathematics ability category are the confusion of which mathematics formula should be used, what steps that should be taken in the problem solving process, and the lack of time to finish all questions. Problems faced by the middle ones are they understand the meaning of the questions but forget the formula to be used, do not understand the next steps, lack of time in finishing the questions, and did not aware of the mistakes they made in counting. Whereas, those who are in low ability did not understand the questions from the beginning, so they totally did not have ability to answer the questions at all.

During the learning process in the class, respondents with high category of mathematics ability directly asked question or tried another way when they experienced problems and have good focus in paying attention to their teachers' explanations. Differently, the middle category felt frustrated when they found difficulty, but they did not brave to ask question, and their focus to the teacher are so easily shifted. Whereas, respondents with low ability only took it for granted in facing the difficulty, they made no effort at all. This is clearly shown on the respondents' work output, where their exam paper sheets contained many blank answers.

Based on observation result and in-depth interview, it is found that the respondents of this research do not understand what metacognitive is. They have done some things that actually included in metacognitive ability category, but they do not aware of it. Things that they have done are more related to the rules made by the dormitory; for example studying hours, the dormitory applies a regular studying hours, all students obey that rule otherwise they will get punishment. Regarding social arithmetic materials, DB needs additional studying time because she feels that she has not fully understood that material. Different from CE who has low mathematics 
ability, $\mathrm{CE}$ does not like mathematics lesson from the beginning so $\mathrm{CE}$ has no motivation to study harder. $\mathrm{CE}$ does not care with bad score in mathematics.

A person who has good mathematics problem solving ability is an individual who can (1) understand a problem, (2) choose the correct strategy to finish the problem, (3) solve the problem correctly and systematically, and (4) directly check the appropriateness of the strategy chosen and the correctness of problem solving applied (Polya, 1973). The high mathematic ability category respondents in Grade VII can perform the first and second steps, but cannot do the next steps. Grade VII respondents in middle category can perform the first step only, and sometimes they cannot do the second step. Meanwhile, the low mathematics ability category cannot perform the first step. Besides intelligence, this is related to self-motivation.

Based on the research result, generally, they have low cognitive knowledge, even though the respondents have high mathematics ability level. The reasons why the native Papua children have low cognitive knowledge are because they do not have control in studying, they are not good in remembering and arranging information, and do not have certain learning strategy. The inability to memorize information is an aspect that the teachers always complain in teaching the native Papua students. Almost all native Papua children who are studying in School of Indonesian Children have problem in remembering information. One of the ways that the teachers do to overcome this problem is by doing habitation, for example having a habit of practicing particular question type. Even though the habitation has been applied, there are some students who cannot do different question from the same type.

These Papua students in their daily life at school and dormitory appear to have cognitive knowledge ability. However, in reality, they do all of their activities because of their teacher. If the teacher do not order or instruct them to do something, they will not do it. For example, strategy in studying, the dormitory has arranged in certain way to enable the students to study and do their activities well, the teacher also tell the students to study, even more, some teachers also teach them in detail to the studying time arrangement part.

There are five sub components in cognitive regulation components that include: planning, information management strategy, monitoring, debugging strategy, and evaluation. The high category respondents have done some aspects in the indicators of planning, information management strategy, monitoring, debugging strategy, and evaluation. In the planning indicator, for instance, the high category respondents have done something like making study plan several days before the test, managing their study time well, determining a purpose before starting a task. DB and JG did all of those things and it can be proven from their on-time assignment submission. This is far different from respondents YR and CE who cannot meet the aspects of planning indicator, they cannot manage their time well, this is shown from their lateness in evening study time, and they did not submit or finish their tasks on-time.

Monitoring indicator has several aspects that covers reviewing learning material regularly, analyze the strategy, and check their understanding. Those aspects are not always done by all respondents consciously. Respondents are always given reminder to do this and that by the teachers and the dormitory supervisor. Respondents who are a little bit conscious to do all those things are those who are in high and middle mathematics ability categories.

The use of cognitive knowledge and cognitive regulation in mathematics problem solving owned by Papua students at Grade VII depends on self-awareness and mathematics ability category level. Students who have high mathematic ability level category has better cognitive knowledge and regulation compared to student with middle or low mathematic ability level categories. However, this is also influenced by the background of their cultural characteristic, where most of them generally do not like to think complicatedly and ignore particular information or forgetful.

\subsection{The Result of Mathematics Test}

Based on the test, interview, and observation results conducted during the research, DB has high metacognitive awareness level. However, in practice or reality, in finishing arithmetic narrative/verbal questions, DB experienced confusion in understanding the problem, in determining formula to be used, and the way to use it. This is because of the influence of several things, such as panicky in DB's self because of the working time allocated, and insufficient understanding about the questions. In terms of planning, DB did it very well, and also always made good preparation for test or even if there is no test.

Both pictures below show the test result of DB. It can be seen from the pictures the way DB finish verbal question of social arithmetic mathematics. DB did the test by writing the content of the question first, DB did this for five questions. Each question is given some space for the answer. Question number 1 has five questions that related one to each other. The question that can be answered correctly by DB is the first question. DB made 
incorrect answers for the second until the fourth questions. DB did not answer question five. The second question is easier that the first one, because question number 2 only has 1 question. However, the solution for number two needs more than one step. DB only answered until the first step, DB cannot answer the further step.

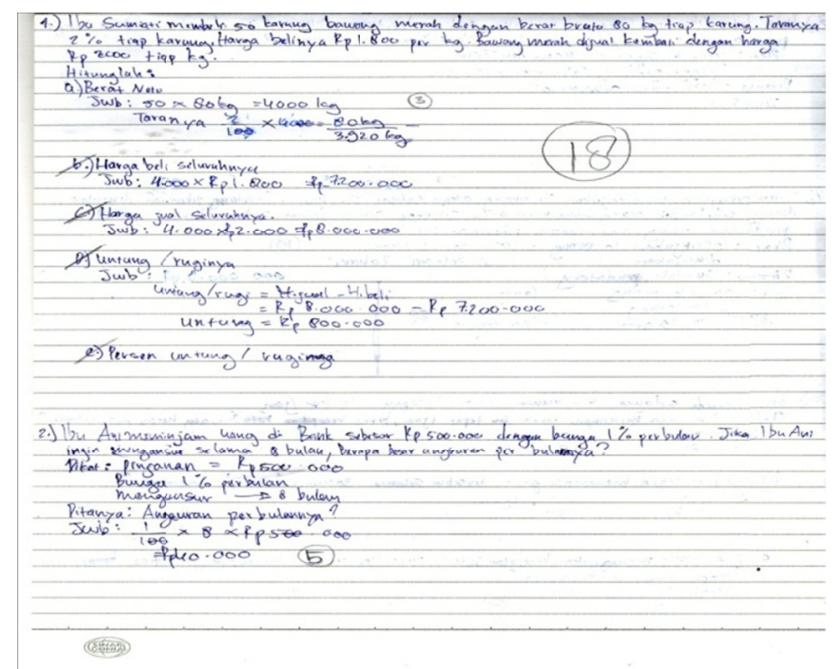

Figure 1. DB's Test Result of Verba/Narrativel Question (1)

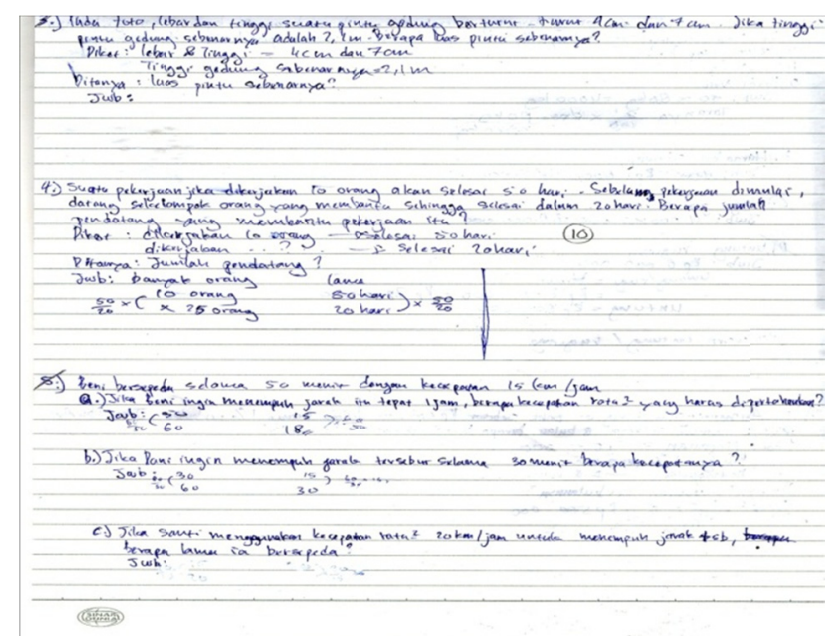

Figure 2. DB Test Result of Verbal/Narrative Question (2)

To make it clearer, the following table explains the result of the analysis of question done by DB based on the order of the question.

Table 1. DB's Working Result Analysis

\begin{tabular}{|c|c|c|}
\hline $\begin{array}{l}\text { Question } \\
\text { Number }\end{array}$ & Question & Analysis \\
\hline \multirow[t]{5}{*}{1} & Question a: net weight & Successfully answered by DB correctly. \\
\hline & $\begin{array}{l}\text { Question b: total } \\
\text { buying price }\end{array}$ & $\begin{array}{l}\text { It was answered by DB using a correct way, but the answer was incorrect because DB } \\
\text { used a wrong weight. DB was confused between using } 4000 \mathrm{~kg} \text { or } 3920 \mathrm{~kg} \text {. Finally, } \\
\text { DB chose } 4000 \mathrm{~kg} \text { because it was the total weight. DB totally forgot about tare. }\end{array}$ \\
\hline & $\begin{array}{l}\text { Question c: total selling } \\
\text { price }\end{array}$ & $\begin{array}{l}\text { It was answered by DB with correct way, but the answer was incorrect. In question b, } \\
\text { DB chose to use } 4000 \mathrm{~kg} \text {, then, in this question DB also used } 4000 \mathrm{~kg} \text {. }\end{array}$ \\
\hline & $\begin{array}{l}\text { Question d: benefit/ } \\
\text { loss }\end{array}$ & $\begin{array}{l}\text { It was answered by } \mathrm{DB} \text { using correct way, but the answer was incorrect. This question } \\
\text { is related to the previous question because it used the result of the answers of } \\
\text { questions } \mathrm{b} \text { and } \mathrm{c} \text {. }\end{array}$ \\
\hline & $\begin{array}{l}\text { Question e: percentage } \\
\text { of benefit / loss }\end{array}$ & DB did not have time to answer this question. \\
\hline
\end{tabular}




\begin{tabular}{|c|c|c|}
\hline $\begin{array}{l}\text { Question } \\
\text { Number }\end{array}$ & Question & Analysis \\
\hline 2 & $\begin{array}{l}\text { Question: } \\
\text { Installment per month/ } \\
\text { monthly installment }\end{array}$ & $\begin{array}{l}\text { This question needs two solution steps. DB answered using the correct way for the } \\
\text { first step, but did not finish the second step. DB was not aware that the question was } \\
\text { about the monthly installment that must be paid, not only the interest. Therefore, DB } \\
\text { only answered the amount of installment interest for eight months. }\end{array}$ \\
\hline 3 & $\begin{array}{l}\text { Question: } \\
\text { The real size of the } \\
\text { door }\end{array}$ & $\begin{array}{l}\text { DB did not answer this number. DB said that he/she was confused working on number } \\
3 \text {, so he/she skip it and directly answered number } 4 \text {. Unfortunately, there was not } \\
\text { enough time for DB to return to number } 3 \text {. }\end{array}$ \\
\hline 4 & $\begin{array}{l}\text { Question: number of } \\
\text { visitor/new comer who } \\
\text { give assistance }\end{array}$ & $\begin{array}{l}\text { DB only answered a part of comparison. DB understood that the question was about } \\
\text { comparison. However, DB was confused to determine the comparison model. It can be } \\
\text { seen that DB was wrong in determining the comparison model. }\end{array}$ \\
\hline \multirow[t]{4}{*}{5} & $\begin{array}{l}\text { Question a: } \\
\text { Average speed for } 1 \\
\text { hour time }\end{array}$ & $\begin{array}{l}\text { There was no answered written. There was only a scratch on comparison model. } \\
\text { Because of the time was running out, DB was panic. The time left to finish the } \\
\text { question was } 15 \text { minutes. }\end{array}$ \\
\hline & $\begin{array}{l}\text { Question b: } \\
\text { Average speed for } 30 \\
\text { minutes time }\end{array}$ & $\begin{array}{l}\text { There was no answered written. There was only a scratch on comparison model. } \\
\text { Because of the time was running out, DB was panic. The time left to finish the } \\
\text { question was } 15 \text { minutes. }\end{array}$ \\
\hline & Question c: & There was a comparison model that was then omitted. \\
\hline & $\begin{array}{l}\text { Average speed is } 20 \\
\mathrm{~km} / \text { hour, how much is } \\
\text { the time? }\end{array}$ & \\
\hline
\end{tabular}

Based on the analysis table above, it can be seen that DB did not use the time effectively. DB wasted time to do question number 1 , so when DB started doing the other number, there was so limited time left. When DB realized that he has run out of time, DB was panic and lost focus. This resulted to the result of the answers from number 2 until 5, in which DB answered them correctly but incomplete.

$\mathrm{CE}$ is one of the respondents in low mathematics ability category. Based on the result of test, interview, and observation result, $\mathrm{CE}$ has low metacognitive awareness. On test question, $\mathrm{CE}$ can only answered question 1 completely. Other questions were not answered, $\mathrm{CE}$ only write the question numbers only. Even though number 1 was finished by $\mathrm{CE}$ and $\mathrm{CE}$ wrote the working step, the answer was incorrect. $\mathrm{CE}$ was seen working on the questions calmly at the back row, time given by teacher was 90 minutes to finish all 5 questions. CE seemed so seriously when answering the questions, but in fact, CE did not do it at all because of lack of understanding. CE used correct steps/way only for number 1 part a, but the calculation was incorrect. Meanwhile, for the other numbers, $\mathrm{CE}$ only wrote the number of the questions. The following was CE's working result.

The problem solving steps created by George Polya (in Anom, 2015) can be clearly seen in the following picture. From all five numbers, CE was only able to finish one question, i.e. question number 1 and the answer was incorrect.

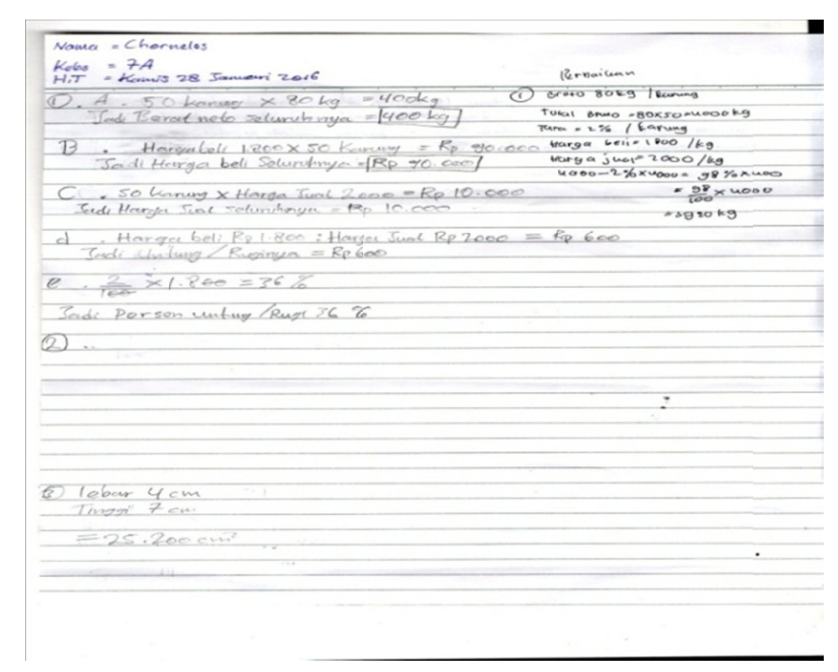

Figure 3. CE's Test Result of Verbal/Narrative Question 
The following table explained the result of analysis of what CE did to answer each question.

Table 2. CE's Working Result Analysis

\begin{tabular}{|c|c|c|}
\hline $\begin{array}{l}\text { Question } \\
\text { Number }\end{array}$ & Question & Analysis \\
\hline \multirow{5}{*}{1.} & $\begin{array}{l}\text { Question a: } \\
\text { net weight }\end{array}$ & $\begin{array}{l}\text { CE used correct way for the first step, but wrong in calculation. CE said that he/she forgot to add } \\
\text { 'zero'. CE did not write the second step because he/she did not know how to find the total net } \\
\text { weight. CE did not understand gross and net. }\end{array}$ \\
\hline & $\begin{array}{l}\text { Question b: } \\
\text { total buying price }\end{array}$ & $\begin{array}{l}\text { CE did not understand the meaning of gross and net, so CE did not answer the second question. } \\
\text { Steps used by CE was wrong, he } / \text { she wrote } 1800 \text { x } 50 \text { sags. In fact, it was clearly written in the } \\
\text { question that the buying price was } 1800 / \mathrm{kg} \text { per sag. }\end{array}$ \\
\hline & $\begin{array}{l}\text { Question c: } \\
\text { total selling price }\end{array}$ & $\begin{array}{l}\text { Similar to the second question. CE did not answer the question correctly. CE only wrote } 50 \text { sags } \\
\text { x } 2000 \text {, in fact, in the question it was clearly written that the selling price was } 2000 / \mathrm{kg} \text {. It means } \\
\text { that the price for } 1 \mathrm{~kg} \text { is } 2000 \text {. }\end{array}$ \\
\hline & $\begin{array}{l}\text { Question d: } \\
\text { benefit/loss }\end{array}$ & $\begin{array}{l}\text { CE did not understand the meaning of benefit and loss. CE said that to him/her, benefit means if } \\
\text { we get some money and loss means if we lost our money. However, CE did not know how or } \\
\text { what formula to use to count the benefit or loss. This is shown in the working steps written, CE } \\
\text { wrote that benefit/loss was buying price divided by selling price. } 1800: 2000 \text { and the answer was } \\
600 \text {. It is very clear that CE does not understand the division operation. }\end{array}$ \\
\hline & $\begin{array}{l}\text { Question: percentage of } \\
\text { benefit/loss }\end{array}$ & CE did not know how to count the percentage of benefit/loss. \\
\hline 2. & $\begin{array}{l}\text { Question: } \\
\text { Installment per month/ } \\
\text { monthly installment }\end{array}$ & $\begin{array}{l}\text { Question } 2 \text { was not answered, only the question number was written. CE was confused about } \\
\text { question number } 2 \text {, so CE directly did number } 3 \text {. }\end{array}$ \\
\hline 3. & $\begin{array}{l}\text { Question: } \\
\text { The real size of the door }\end{array}$ & $\begin{array}{l}\text { CE only wrote the information of the width and the length of the door, then, there was a number } \\
25.200 \mathrm{~cm} 2 \text { appear. When the researcher asked where the number comes from, CE could not } \\
\text { answer it. He said that he only counted it with counting operation multiply and division. }\end{array}$ \\
\hline 4. & $\begin{array}{l}\text { Question: number of } \\
\text { visitor/new comer who } \\
\text { give assistance }\end{array}$ & It was not answered at all. There was not even the question number written. \\
\hline \multirow{3}{*}{5.} & $\begin{array}{l}\text { Question a: } \\
\text { Average speed for } 1 \text { hour } \\
\text { time }\end{array}$ & It was not answered at all. There was not even the question number written. \\
\hline & $\begin{array}{l}\text { Question b: } \\
\text { Average speed for } 30 \\
\text { minutes time }\end{array}$ & It was not answered at all. There was not even the question number written. \\
\hline & $\begin{array}{l}\text { Question c: } \\
\text { Average speed is } 20 \\
\mathrm{~km} / \text { hour, how much is the } \\
\text { time? }\end{array}$ & It was not answered at all. There was not even the question number written. \\
\hline
\end{tabular}

CE said that he/she dislike mathematics. On Wednesday evening before the test was conducted, CE studied together with his/her friends in Grade VII classroom and did the homework given by the teacher as materials description of the Thursday morning test. Researcher observed that CE sat alone in the corner of the class, he/she did not minggle with his/her friends. After some times, CE approached his/her friend to ask questions, his/her friend explained the material to $\mathrm{CE}$ who nodded his/her head several times and responded to several questions. Materials that $\mathrm{CE}$ asked were about nett, gross, and tare.

The result collected from other respondents shows different results. JG got the best test result among the six respondents. JG is a type of fast thinking but careless person. JG did not re-check his/her work, as a result, there are lots of minor mistakes that he/she could actually fixed by JG. This proves that JG has good enough cognitive knowledge ability, that is declarative knowledge, but JG has bad cognitive regulation, that is planning, monitoring, and evaluation parts.

Metacognitive awareness owned by DY is low enough, especially inn declarative knowledge indicator. DY 
cannot remember information well, it means that inn working on the questions, DY had difficulty in remembering the formula and arrange/manage the information he/she received. The result of the test was also unsatisfied, even though DY had done better preparation.

LD has a bad planning because he/she did not prepare himself/herself seriously before the test. LD said that he/she could not manage his/her time between playing and studying, even though there is a schedule made by the dormitory. Therefore, it can be concluded that LD has low metacognitive awareness. LD did not finish the test because he/she ran out of time. LD took too much time to think of particular question.

YR does not understand the problem of each question. The first step that must be done in the process of problem solving according to George Polya (in Anom, 2015) is to understand that problem. If someone understands a problem in the question, then he/she can write all information in the question and questioned in the question. YR did not understand the problem in the question, so YR could not go forward to the next step, i.e. planning the way to solution.

Generally, it can be said that metacognitive awareness of the six respondents are very low. From the six respondents, students who have the best metacognitive awareness are DB and JG, whereas the others are still very low, especially CE Many other factors that influence CE's low metacognitive awareness inn mathematics problem solving, for example, their dislike to mathematics is one of the cause.

\section{Conclusion}

Based on the data analysis conducted, it is found that Papua students at Grade VII do not understand and do not know about metacognitive in problem solving process in learning mathematics. Papuan students do not have good metacognitive ability (low cognitive knowledge and cognitive regulation), they cannot do activities that reflect metacognitive consciously. In other word, students need to be ordered or given reminder first before doing something. From the six respondents, only respondents with high mathematics ability category who have good declarative knowledge but relatively low procedural and conditional knowledge. For the middle mathematics ability category, they can only follow their teacher's orders. They even break what the teacher said. Respondents with low mathematics ability category almost never perform activity that reflects metacognitive. They always need to be given reminder and sometimes even if they have been. Given reminder, they still do not do it (low cognitive regulation).

Metacognitive awareness of local Papua students will influence their mathematics ability. If someone has good mathematics ability, then he/she will also have a good metacognitive awareness, and the other way around. However, for the local Papua people, there are many other factors that influence their metacognitive awareness, for example their life background in Papua such as massive culture, women only give birth, economy, teachers, and education facilities, educational opportunity, difficulty in getting support, and it is worsen because of the lack of Governmental program in Papua to encourage people to school, for example Papua Smart Children program.

Based on these result facts of the research, then a teacher must extra hard work in teaching the Papuan students. The teacher must understand each student, so they must approach them first, such as stay with them in dormitory, interact in daily life, and ask the students to read diligently so that the vocabulary of students in Indonesian language increases. Teacher also have to learn Papuan languages, because it's help to approach them. Initially the way of teaching will be slightly different from the way of teaching to students who have the ability that match to the level grade. Teachers will teach slower than usual.

The Papuan students must learn Indonesian language before start the school. School of Indonesian Children can make a matriculation language program. If they already fluent in Indonesian language, they can understand the other problem in another subject lesson. For mathematics, they must practice everyday so they can understand the mathematical problem solving. However, if Papuan students are trained intensively then Papuan students will be the same as students in general. The research can be advanced on teaching methods that suitable for Papuan students, or classroom action research.

\section{References}

Creswell, J. W. (2012). Educational research: Planning, conducting and evaluating quantitative and qualitative research (4th ed.). Boston, MA: Pearson Education, Inc.

David, R. K. (2002). A revision of bloom's taxonomy: An overview. Theory into practice, 41(4), $212-218$. http://dx.doi.org/10.1207/s15430421tip4104_2

Hurtado, A., \& Gurin, P. (1995). Ethnic Identitiy and Bilingualism Attitudes. In A. Padilla (Ed.), Hispanic 
Psychology. Sage, Thousand Oaks, CA.

Supriyono, J. (2010). Melangkah ke dunia luas: Impian pergulatan anak-anak daerah papua. Papua: Lembaga Pendidikan Daerah Papua.

Polya, G. (1973). How to solve it: A new aspect of mathematical method. New Jersey: Princeton University Press.

Miller, P., \& Hoogstra, L. (1992). Language as tool in the socialization and apprehension of cultural meanings. In T. Schwartz, G. White, \& C. Lutz (Eds.), New Directions in Physhological Anthropology. New York: Cambridge University Press.

Widjojo, M. S. (2009). Daerah papua road map: Negotiating the past, improving the present, and securing the future. Jakarta: Obor.

NCTM. (2000). Principles and Standars for School Mathematics. Reston: The National Council of Teachers of Mathematics Inc.

Santrock, J.W. (2001). Child Development. Boston: McGraw-Hill.

Schraw, G., \& Dennison, S. R. (1994). Assessing metacognitive awareness. Contempory Educational Psychology, 19(4), 460-475. https://doi.org/10.1006/ceps.1994.1033

Susiyati. (2014). Kemampuan Berpikir Kritis dan Kreatif Matematik dalam Pemecahan Masalah (Vol. 1.). Prosiding Seminar Nasional Pendidikan Matematika Program Pasca Sarjana STKIP Siliwangi.

Tim Pengembang Ilmu Pendididkan FIP-UPI. (2007). Ilmu dan Aplikasi pendidikan Bagian 3. Bandung: PT. Imperial Bhakti Utama.

Wempi, W., \& Marthen, M. (2015). Gunung versus pantai: Dalam perspektif nilai-nilai hidup bersama. Yogyakarta: Asda Media.

\section{Copyrights}

Copyright for this article is retained by the author(s), with first publication rights granted to the journal.

This is an open-access article distributed under the terms and conditions of the Creative Commons Attribution license (http://creativecommons.org/licenses/by/4.0/). 